\title{
Pemberian Topikal Ekstrak Daun Pepaya (Carica papaya) pada Hewan Coba Mencit (Mus musculus) Bunting Meningkatkan Kepadatan Kolagen Jaringan Vagina
}

\author{
Fauzan Djunaidi', Eighty Mardiyan K', Widjiati ${ }^{2}$ \\ 'Departemen Obstetri dan Ginekologi, Fakultas Kedokteran Universitas Airlangga, RSUD dr. Soetomo, Surabaya \\ ${ }^{2}$ Departemen Embriologi Veteriner, Fakultas Kedokteran Hewan Universitas Airlangga
}

\section{ABSTRAK}

Tujuan: Menganalisis pengaruh pemberian gel ekstrak air daun pepaya terhadap kepadatan kolagen jaringan vagina pasca melahirkan pada hewan coba mencit saat bunting.

Bahan dan Metode: Desain penelitian randomized post test only control group,dilakukan di Departemen Embriologi Veteriner, Fakultas Kedokteran Hewan, Universitas Airlangga, pada bulan April-Juni 2015. Terdapat empat kelompok, masing-masing kelompok terdiri dari 8 mencit bunting. Kelompok kontrol (tanpa perlakuan) dan kelompok perlakuan berupa pemberian topikal ekstrak daun pepaya konsentrasi 5\%,10\% dan 15\%, 1x/hari pervaginam, sejak usia kebuntingan hari ke-12 sampai melahirkan. Lama perlakuan 6-8 hari. Setelah melahirkan, mencit dikorbankan dan diperiksa kepadatan kolagen dengan pewarnaan HE. Uji statistik yang dipakai uji parametrik dan nonparametrik disertai uji komparasi ganda

Hasil: Kepadatan kolagen berdasarkan skor didapatkan nilai median pada kelompok I = 3,5 (3-4); kelompok II = 4 (4-4); kelompok III = 3 (3-4); kelompok IV = 4 (3-4) dengan uji Kruskal-Wallis $(\mathrm{p}=0,036)$ menunjukkan perbedaan signifikan, dilanjutkan uji beda tiap kelompok Mann-Whitney, hasilnya tidak didapatkan perbedaan signifikan antara kelompok kontrol dengan masing-masing kelompok perlakuan. Kepadatan kolagen berdasarkan persentase didapatkan nilai rerata pada kelompok I = $90,64 \% \pm 3,35$; kelompok II $=96,19 \% \pm 1,34$; kelompok III $=$ $87,85 \% \pm 6,69$ dan kelompok IV $=92,08 \% \pm 4,84$. Uji Anova menunjukkan perbedaan signifikan $(\mathrm{p}=0,032)$, dilanjutkan uji beda LSD menunjukkan perbedaan bermakna antara kelompok I dan II $(\mathrm{p}=0,045)$

Simpulan: pemberian topikal ekstrak daun pepaya konsentrasi $5 \%$ pervaginam saat masa kebuntingan mencit meningkatan kepadatan kolagen jaringan vagina pasca melahirkan

Kata kunci: prolaps organ panggul pasca salin, jaringan kolagen, ekstrak daun pepaya

\section{ABSTRACT}

Objective: To analyze extract water gel of papaya leaf effect against vaginal tissue collagen density in experimental pregnant mice

Materials and Methods: Randomized post test only control group design. Research was conducted in the Department of Veterinary Embryology, Faculty of Veterinary Medicine, University of Airlangga, in April-June 2015. There is four groups, each of which there are 8 groups of pregnant mice. The control group without treatment, while three other groups get treated with topical extract of papaya leaf, concentration $5 \%, 10 \%, 15 \%$, once time daily vaginally, since the age of the 12th day of gestation until birth. Treatment ranges from 6-8 days. After delivery, mice were sacrificed and examined the density of collagen with $\mathrm{HE}$ staining. The statistical test used is parametric and nonparametric tests, accompanied by multiple comparison test

Results: Collagen density based on the scores obtained median value in group I = 3.5 (3-4); group II = 4 (4-4); group III = 3 (34); group IV = $4(3-4)$, Kruskal-Wallis test $(p=0.036)$ showed significant difference, comparative test Mann-Whitney each group, the results were not found significant differences between the control group with each treatment group. Collagen density based on the percentage obtained mean values in group I $(90.64 \%$ $\pm 3.35)$; group II $(96.19 \% \pm 1.34)$; group III $(87.85 \% \pm 6.69)$ and group IV $(92.08 \% \pm 4.84)$. ANOVA test showed significant difference $(\mathrm{p}=0.032)$, and LSD comparative test showed significant differences between groups I and II ( $\mathrm{p}=0.045)$

Conclusion: topical administration of papaya leaf extract with concentration $5 \%$ vaginally, in the period of gestation in mice, increase collagen density in postpartum vaginal tissue

Keywords: postpartum pelvic organ prolapse, collagen, papaya leaf extract

Correspondence: Fauzan Djunaidi, Departemen Obstetri \& Ginekologi, Fakultas Kedokteran Universitas Airlangga, RSUD Dr. Soetomo, Surabaya, Jawa Timur, Indonesia, phone:+6281330584983, email: fauzan_djunaidi@yahoo.com.

\section{PENDAHULUAN}

Setiap wanita menginginkan persalinannya berjalan lancar dan dapat melahirkan bayi yang sempurna. Ada dua cara persalinan, yaitu persalinan per vaginam, lebih dikenal dengan persalinan normal atau alami dan persalinan dengan operasi sesar yaitu tindakan operasi untuk mengeluarkan bayi dengan melakukan insisi atau pemotongan pada kulit, otot perut, serta rahim ibu. ${ }^{1}$ Lebih dari $85 \%$ perempuan dengan persalinan per vaginam mengalami ruptur perinei, yaitu sekitar 60$70 \%$ pada tahun 1997. Ruptur perinei yang lebih berat berupa ruptur sfingter anal bervariasi antara $0,5 \%$ di Inggris, 2,5\% di Denmark, dan 7\% di Kanada., ${ }^{2,3,4}$ Ruptur perinei yang terjadi pada saat melahirkan spontan atau dibantu, biasanya terjadi lebih berat pada persalinan per vaginam pertama kali. Faktor risiko yang berhubungan meliputi besarnya ukuran janin, cara persalinan, malpresentasi dan malposisi janin. Faktor maternal lain yang dapat meningkatkan cakupan dan tingkat trauma adalah etnis (perempuan kulit putih lebih beresiko dari pada wanita hitam), usia lebih tua, sintesis kolagen abnormal dan status gizi buruk., 
Sayangnya morbiditas pada perineum, vagina dan sekitarnya setelah melahirkan, kurang mendapat perhatian. $^{7}$ Padahal kekuatan otot dasar panggul dan jaringan pendukung organ panggul ditentukan berbagai macam kejadian selama kehidupan seorang wanita, yaitu kehamilan dan persalinan yang pengaruhnya cukup besar pada anatomi dan fisiologi wanita. Setelah itu, penuaan dan menopause memiliki efek berikutnya pada organ panggul. ${ }^{8}$ Efek jangka panjang pada organ ginekologi tersebut berupa prolaps organ panggul, inkontinensia urin tipe stres, ruptur perinei seperti disebutkan di atas dan gejala sisa setelah perbaikan berupa nyeri perineum dan dispareunia. ${ }^{8}$ Women's Health Initiative melaporkan prevalensi prolaps organ panggul sekitar $41 \%$ pada wanita usia 50-79\%, berupa sistokel $34 \%$, rektokel $19 \%$ dan prolaps uterus $14 \%$.

Keseimbangan sintesa dan degradasi kolagen penting dalam menjaga integritas jaringan dan kekuatan regangan selama remodelling jaringan berlangsung. ${ }^{10}$ Dimana proses kehamilan dan persalinan meyebabkan peregangan dan merusak dasar panggul melalui mekanisme cedera saraf, otot dan fasia endopelvik. Serta pemeriksaan histologis levator ani baik pada tikus pasca meahirkan maupun cadaver manusia menunjukkan kepadatan serat otot berkurang. ${ }^{8}$ Maka sintesa kolagen diperlukan selama proses tersebut (kehamilan sampai dengan persalinan) untuk membentuk keseimbangan/ homeostasis.

Pengobatan alternatif dengan menggunakan tanaman tradisional, salah satunya adalah daun pepaya (Carica papaya). Dikatakan bahwa daun pepaya memiliki efek anti bakteri, anti inflamasi, analgesik, digestan dan laxative. ${ }^{11}$ Ekstrak daun pepaya ternyata mengandung zat kimiawi juga, yaitu zat aktif papain, alkaloid, flavonoid, tanin, saponin, steroid, glikosid serta vitamin C. $^{11,12}$ Kandungan saponin dan vitamin $\mathrm{C}$ ini yang berperan dalam sintesa kolagen. ${ }^{13}$

\section{BAHAN DAN METODE}

Desain penelitian adalah randomized post test only control group design.Penelitian dilakukan di Departemen Embriologi \& Departemen Patologi Anatomi Veteriner Fakultas Kedokteran Hewan serta Departemen Fitokimia \& Farmakokognisi Fakultas Farmasi, Universitas Airlangga, pada bulan April-Juni 2015.

Sampel penelitian ini adalah tiga puluh dua mencit yang terbagi menjadi empat kelompok, yang masing-masing kelompok terdapat delapan mencit. Usia mencit 3-4 bulan, berat 20-30 gram, belum pernah bunting sebelumnya, sehat dan nantinya melahirkan 6-10 anak mencit. Kelompok kontrol tanpa perlakuan, sedangkan tiga kelompok lain mendapatkan perlakuan gel ekstrak air daun pepaya 1x/hari, sejak usia kebuntingan hari ke12 sampai melahirkan. Setelah melahirkan, mencit dikorbankan dan diperiksa kepadatan kolagen jaringan vagina dengan pewarnaan $\mathrm{HE}$ (hematoxylin eosin). Hasilnya diuji statistik berupa uji parametrik dan nonparametrik, disertai uji komparasi ganda. Sebelumnya telah dilakukan studi pendahuluan karena kami tidak mendapatkan literatur yang menyatakan ada tidaknya perbedaan kepadatan kolagen pada hewan coba mencit antara yang non bunting dan bunting.

\section{HASIL DAN PEMBAHASAN}

Hasil kepadatan kolagen pada mencit non bunting berdasar skor didapatkan nilai median 3 (3-4) dan berdasar persentase 78,61\% (59,12 - 92,63). Sedangkan pada mencit bunting tanpa perlakuan, kepadatan kolagen berdasar skor didapatkan nilai median 3 (2-3) dan berdasar persentase 76,90\% $(30,01-88,14)$. Ada perbedaan sedikit, dimana kepadatan kolagen lebih rapat pada mencit tanpa proses bunting dan melahirkan. Selanjutnya kami lakukan uji statistik non parametrik Mann-Whitney, didapatkan hasil perbedaan yang tidak signifikan, yaitu berdasar skor $\mathrm{p}=0,16$ dan berdasar persentase $p=0,59 \quad(p>0,05)$. Sehingga tidak ada perbedaan kondisi kolagen pada vagina mencit bunting dan non bunting.

Tabel 1. Skor Kepadatan Kolagen antara mencit bunting dan non bunting

\begin{tabular}{lcc}
\hline \multicolumn{1}{c}{ Kelompok } & Median (Min-Max) & $\mathrm{p}$ \\
\hline Non bunting & $3,0(3-4)$ & 0,16 \\
Bunting & $3,0(2-3)$ & \\
\hline
\end{tabular}

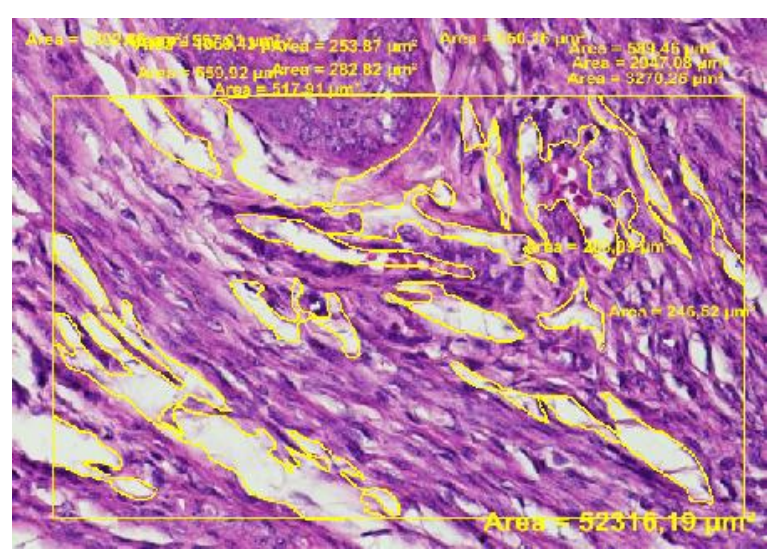

Gambar 1. Pengukuran kepadatan kolagen pada mencit non bunting (studi pendahuluan) 
Tabel 2. Kepadatan Kolagen berdasar persentase antara mencit bunting dan non bunting

\begin{tabular}{lcc}
\hline \multicolumn{1}{c}{ Kelompok } & Median (Min-Max) & $\mathrm{p}$ \\
\hline Non bunting & $78,61(59,12-92,63)$ & 0 \\
Bunting & $76,90(30,01-88,14)$ & \\
\hline
\end{tabular}

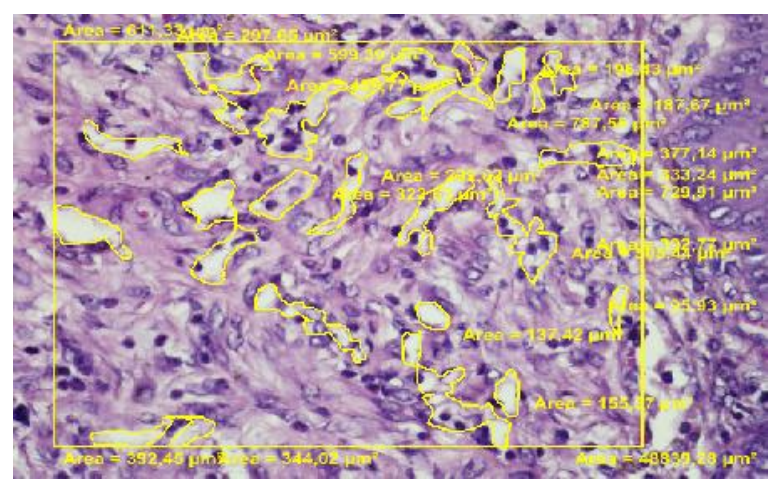

Gambar 2. Pengukuran kepadatan kolagen pada mencit bunting (studi pendahuluan)

Pada studi lanjutan (kontrol vs perlakuan), kami ambil 24 mencit, masing-masing kelompok sebanyak 6 mencit (sesuai rumus sampel), lalu kami tinjau karakteristiknya ditinjau dari berat badan induk saat bunting, berat badan fetus, panjang badan fetus, jumlah fetus yang dilahirkan per induk, ada/tidaknya cacat eksternal dan hari kebuntingan saat mencit melahirkan.

Berat badan induk telah homogen sebelum perlakuan yaitu berkisar antara 20-25 gram. Berat badan induk saat bunting hari ke-15 ditimbang karena kekhawatiran tidak sempat ditimbang bila lahir terlebih dahulu karena efek perlakuan, ternyata lahirnya anak mencit sebelum usia bunting 17 hari tidak terjadi. Berat induk terberat adalah 45 gram.

Berat badan fetus masih dalam taraf normal, normalnya berat badan anak mencitantara $0,5-1,5$ gram. ${ }^{14}$ Tidak didapatkan cacat eksternal dari semua kelompok (berat lahir rendah, anggota tubuh tidak lengkap, mati).
Tidak didapatkan proses kelahiran anak mencit yang kurang dari 17 hari atau lebih dari 19 hari usia kebuntingan. Sedangkan jumlah anak fetus yang dilahirkan berkisar antara 3-15 fetus per induk. Namun yang diambil sebagai sampel untuk uji statistik adalah vagina induk mencit yang melahirkan anak mencit berjumlah 6-10, karena rata-rata mencit melahirkan 6-10, beberapa literatur menyebutkan 5-10. ${ }^{14}$

Secara keseluruhan data homogen dengan nilai yang tidak berbeda signifikan $(>0,05)$. Lama aplikasi gel berkisar 6-8 hari. Pada studi lain dilakukan aplikasi ekstrak daun pepaya pada gusi mencit terinfeksi \pm 6 hari dan aplikasi pada luka tikus $\pm 23-28$ hari. ${ }^{11,15}$

Data kepadatan kolagen berdasar skor dari masingmasing kelompok penelitian dilakukan uji normalitas Kolmogorov-Smirnov. Hasil uji didapatkan data terdistribusi tidak normal dengan nilai $\mathrm{p}=0,002(\mathrm{p}<0,05)$, kemudian dilanjutkan dengan pengolahan statistik Kruskall-Wallis dan bila terdapat perbedaan, maka dilanjutkan uji beda Mann-Whitney. Sedangkan kepadatan kolagen berdasar persentase dilakukan pula uji normalitas Kolmogorov-Smirnov dengan hasil $\mathrm{p}=0.20$ ( $>0,05)$ yang artinya data terdistribusi normal, sehingga bisa dilanjutkan ke pengolahan statistik Anova dan bila terdapat perbedaan, maka dilanjutkan uji beda LSD.

Pada penelitian ini, data kepadatan kolagen berdasarkan penilaian skor diuji statistik Kruskal Wallis. Kepadatan kolagen baik berdasarkan skor maupun persentase ada perbedaannya, dari skor dapatkan perbedaan signifiikan, dengan nilai $\mathrm{p}=0,036(\mathrm{p}<0,05)$, namun setelah dilakukan uji beda masing-masing kelompok dengan uji statistik Mann Whitney, ternyata kelompok 1 tidak didapatkan perbedaan bermakna dengan kelompok 2, 3 dan 4 .

Memang dari uji statistik non parametrik KruskalWallis (skor kolagen) ada perbedaan signifikan dengan nilai $\mathrm{p}=0,036$. Setelah uji beda Mann-Whitney didapatkan perbedaan antara kelompok 2 dan 3 (sesama kelompok perlakuan) dengan nilai $\mathrm{p}=0,015 \quad(<0,05)$, bukan antara kontrol dengan perlakuan.

Tabel 3. Karakteristik sampel penelitian

\begin{tabular}{|c|c|c|c|c|c|}
\hline \multirow{2}{*}{ Karakteristik } & \multicolumn{4}{|c|}{ Median (Min-Max) } & \multirow{2}{*}{$\mathrm{p}$} \\
\hline & 1 & 2 & 3 & 4 & \\
\hline $\begin{array}{l}\text { BB Induk Post } \\
\text { (gram) }\end{array}$ & $35(30-45)$ & $30(25-40)$ & $30(25-40)$ & $30(25-30)$ & 0,51 \\
\hline Lahir Hari ke- & $18(17-19)$ & $18(17-19)$ & $18(17-18)$ & $17,5(17-19)$ & 0,79 \\
\hline Jumlah Fetus & $8(6-9)$ & $8(6-10)$ & $6,5(6-10)$ & $7(6-9)$ & 0,54 \\
\hline $\begin{array}{l}\text { BB Fetus } \\
\text { (gram) }\end{array}$ & $1,52(1,46-1,77)$ & $1,61(1,20-1,70)$ & $1,13(0,92-1,24)$ & $1,47(1,30-1,71)$ & 0,37 \\
\hline PB Fetus (cm) & $3,07(2,93-3,22)$ & $2,98(2,90-3,03)$ & $2,81(2,65-2,91)$ & $2,95(2,83-3,13)$ & 0,09 \\
\hline
\end{tabular}


Tabel 4. Hasil Skor Kepadatan Kolagen antarkelompok

\begin{tabular}{ccc}
\hline Kelompok & Median (Min - Max) & $\mathrm{p}$ \\
\hline 1 & $3,5(3-4)$ & \\
2 & $4(4-4)$ & 0,036 \\
3 & $3(3-4)$ & \\
4 & $4(3-4)$ & \\
\hline
\end{tabular}

*uji Kruskal-Wallis

Tabel 5. Hasil Skor Kepadatan Kolagen antara kelompok 1 dan kelompok 2

\begin{tabular}{ccc}
\hline Kelompok & Median (Min - Max) & $\mathrm{p}$ \\
\hline 1 & $3,5(3-4)$ & 0,18 \\
2 & $4(4-4)$ & \\
\hline
\end{tabular}

*uji Mann-Whitney

Tabel 6. Hasil Skor Kepadatan Kolagen antara kelompok 1 dan kelompok 3

\begin{tabular}{ccc}
\hline Kelompok & Median (Min - Max) & $\mathrm{p}$ \\
\hline 1 & $3,5(3-4)$ & 0,39 \\
3 & $3(3-4)$ & \\
\hline
\end{tabular}

*uji Mann-Whitney

Tabel 7. Hasil Skor Kepadatan Kolagen anatara kelompok 1 dan kelompok 4

\begin{tabular}{ccc}
\hline Kelompok & Median (Min - Max $)$ & $\mathrm{p}$ \\
\hline 1 & $3,5(3-4)$ & 0,69 \\
4 & $4(3-4)$ & \\
\hline
\end{tabular}

*uji Mann-Whitney

Tabel 8. Hasil Skor Kepadatan Kolagen berdasar Persentase antarkelompok

\begin{tabular}{ccc}
\hline Kelompok & Mean \pm SD & $\mathrm{p}$ \\
\hline 1 & $90,64 \pm 3,35$ & \\
2 & $96,19 \pm 1,34$ & \\
3 & $87,85 \pm 6,69$ & 0,032 \\
4 & $92,08 \pm 4,84$ & \\
\hline
\end{tabular}

*uji Anova

Namun kepadatan kolagen berdasarkan persentase, dari uji Anova didapatkan perbedaan masing-masing kelompok dengan nilai $\mathrm{p}=0,032$ dan uji beda antara kelompok dengan uji statistik LSD didapatkan perbeda-an.

\section{Kelompok I dan Kelompok 2}

Nilai median skor kepadatan kolagen pada kelompok 1 (kontrol) adalah sebesar 3,5 (3-4). Nilai ini lebih rendah bila dibandingkan dengan skor kepadatan kolagen pada kelompok 2 (perlakuan gel ekstrak air daun pepaya 5\%),yaitu 4 (4-4). Kemudian dilanjutkan uji statistik Mann Whitney, didapatkan nilai $\mathrm{p}=0,18(\mathrm{p}<0,05)$. Artinya, perbedaan nilai tersebut tidak bermakna.
Bila diambil kepadatan kolagen berdasarkan persentase (skala rasio=parametrik) nilai kepadatan kolagen pada kelompok 1 adalah 90,64\% $\pm 3,35$. Sedangkan nilai kepadatan kolagen pada kelompok 2 sebesar 96,19\% \pm 1,34. Pada uji beda statistik LSD didapatkan nilai $\mathrm{p}=0,045 \quad(\mathrm{p}<0,05)$. Ini menunjukkan ada perbedaan bermakna antara rerata kepadatan kolagen kelompok kontrol dengan kelompok perlakuan konsentrasi $5 \%$. Sehingga jaringan kolagen pada perlakuan lebih padat dibanding kontrol.

Tabel 9. Kepadatan Kolagen berdasar Persentase antara kelompok 1 dan kelompok 2

\begin{tabular}{ccc}
\hline Kelompok & Mean \pm SD & $p$ \\
\hline 1 & $90,64 \pm 3,35$ & 0,045 \\
2 & $96,16 \pm 1,34$ & \\
\hline
\end{tabular}

*uji LSD

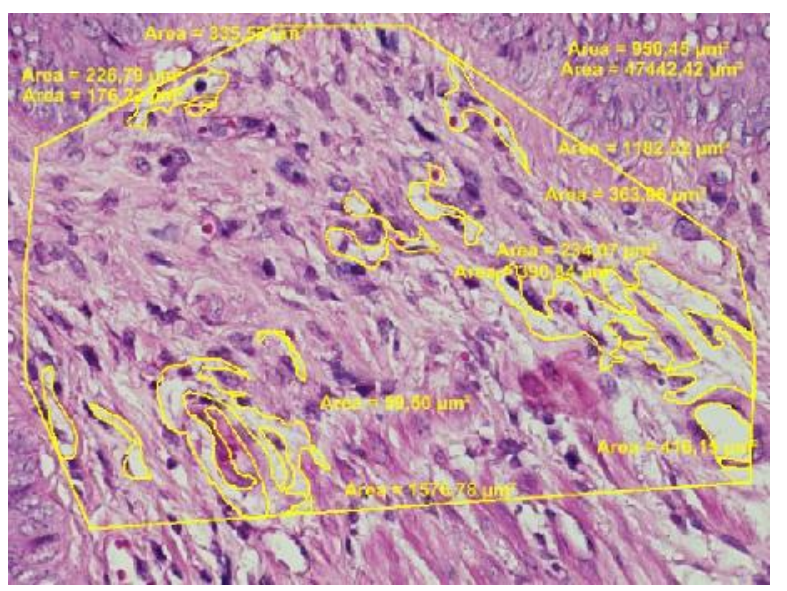

Gambar 3. Kepadatan kolagen kelompok 1

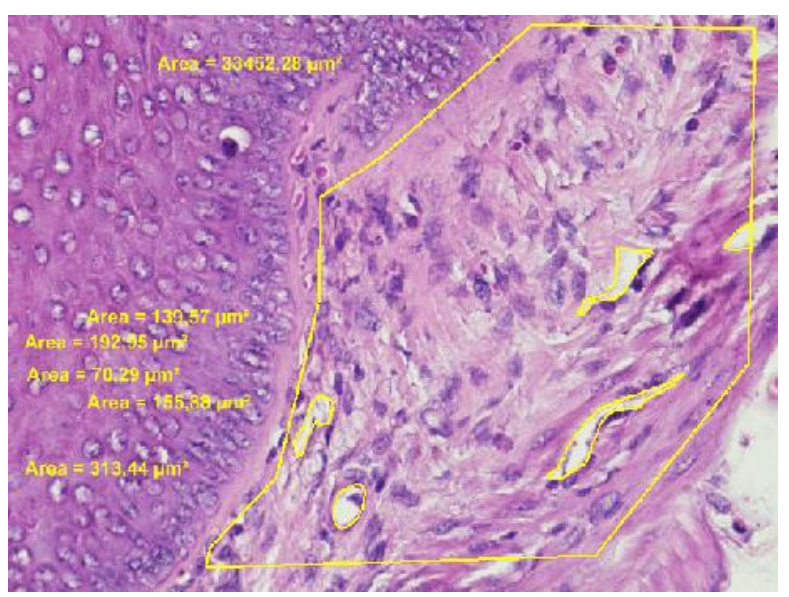

Gambar 4. Kepadatan kolagen kelompok 2 


\section{Kelompok I dan Kelompok 3}

Tabel 10. Kepadatan Kolagen berdasar Persentase antara kelompok 1 dan kelompok 3

\begin{tabular}{ccc}
\hline Kelompok & Mean & $\mathrm{p}$ \\
\hline 1 & $90,64 \pm 3,35$ & 0,29 \\
3 & $87,85 \pm 6,69$ & \\
\hline
\end{tabular}

*uji LSD

Median skor kepadatan kolagen pada kelompok 1 (kontrol) adalah sebesar 3,5 (3-4). Nilai ini lebih tinggi bila dibandingkan dengan skor kepadatan kolagen pada kelompok 3 (perlakuan gel ekstrak air daun pepaya $10 \%$ ), yaitu 3 (3-4). Uji beda dengan Mann-Whitney tidak menunjukkan perbedaan bermakna $(\mathrm{p}=0,394)$. Kepadatan kolagen berdasarkan persentase pada kelompok 1 adalah $90,64 \% \pm 3,35$. Sedangkan nilai kepadatan kolagen pada kelompok 3 sebesar 87,85\% $\pm 6,69$. Pada uji beda statistik LSD didapatkan nilai $\mathrm{p}=0,29$. Tidak ada perbedaan bermakna antararerata ke-padatan kolagen kelompok kontrol dengan kelompok perlakuan konsentrasi $10 \%$.

\section{Kelompok I dan Kelompok 4}

Median skor kepadatan kolagen pada kelompok 1 (kontrol) adalah sebesar 3,5(3-4). Nilai ini lebih rendahdibandingkan dengan skor kepadatan kolagen pada kelompok 4 (perlakuan gel ekstrak air daun pepaya $15 \%)$, yaitu 4 (3-4). Uji beda dengan Mann-Whitney tidak menunjukkan perbedaan bermakna $(p=0,69)$. Kepadatan kolagen berdasarkan persentase pada kelompok 1 adalah $90,64 \% \pm 3,35$. Sedangkan nilai kepadatan kolagen pada kelompok 4 sebesar 92,08\% \pm 4,83. Pada uji beda statistik LSD didapatkan nilai $\mathrm{p}=0,58$. Tidak ada perbedaan bermakna antararerata kepadatan kolagen berdasar persentase kelompok kontrol dengan kelompok perlakuan konsentrasi $15 \%$.

Tabel 11. Kepadatan Kolagen berdasar Persentase antara kelompok 1 dan kelompok 4

\begin{tabular}{ccc}
\hline Kelompok & Mean & $\mathrm{p}$ \\
\hline 1 & $90,64 \pm 3,35$ & \multirow{2}{*}{0,58} \\
4 & $92,08 \pm 4,84$ & \\
\hline
\end{tabular}

*uji LSD

Kehamilan dan persalinan pervaginam dihubungkan dengan gangguan fungsiotot dasar panggul seperti inkontinensia urin tipe stres dan prolap organ panggul. ${ }^{16}$ Kehamilan dan persalinan menyebabkan dasar panggul melemah atau rusak sehingga tidak dapat berfungsi dengan baik. Kekendoran otot-otot yang melingkari vagina sering disebabkan oleh persalinan pervaginam.

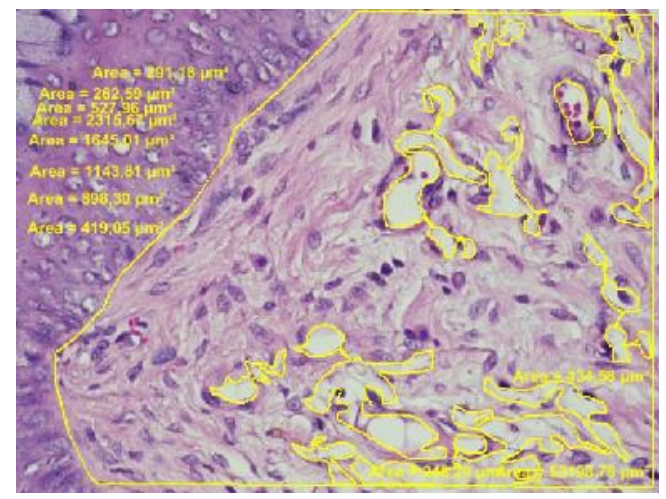

Gambar 5. Kepadatan kolagen kelompok 3

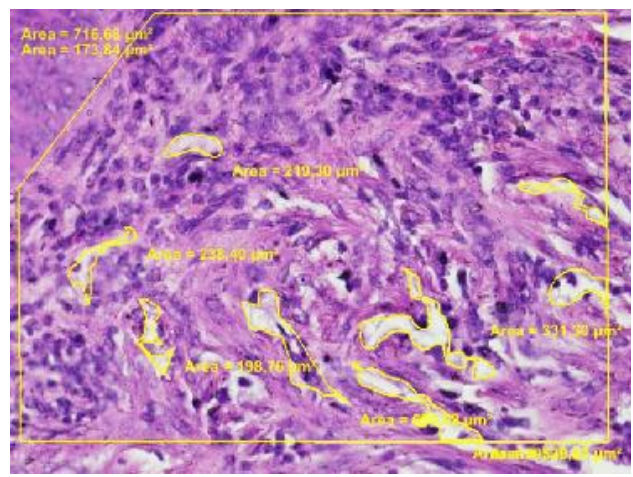

Gambar 6. Kepadatan kolagen kelompok 4

Hampir 50\% wanita yang pernah melahirkan akan menderita prolap organ genitourinaria dan $40 \%$ disertai inkontinensia urin. Diantara kondisi ini, inkontinensia urin merupakan salah satu yang paling tinggi prevalensinya. Analisis Cochrane menyatakan satu dari tiga wanita akan mengalami kebocoran urin dan satu dari sepuluh mengalami kebocoran feses selama hidupnya dimana lebih $65 \%$ wanita ini menyatakan bahwa hal tersebut dimulai saat kehamilan maupun sesudah melahirkan. ${ }^{17}$

Sejauh ini bukti yang ditunjukkanmendukunghal berikut: Persalinan pervaginam menyebabkan kerusakan langsung pada otot panggul termasuk struktur penyangga dan sfingternya. ${ }^{16}$ Persalinan pervaginam menyebabkan trauma tidak langsung pada otot pelvis dan sfingter dengan derajat denervasi yang bervariasi. Baik kerusakan langsung maupun tidak langsung selama persalinan pervaginam dapat berkembang menjadi prolaps uterovagina dan selanjutnya menjadi inkontinensia fecal dan urin. Sementara itu proses kehamilan dan persalinan menyebabkan gangguan dasar panggul antara lain melalui mekanisme, yaitu cedera otot (miogenik), cedera fasia endopelvik, pengaruh hormonal dan gangguan kolagen. ${ }^{8}$ 
Penelitian ini dilakukan untuk mengetahui ada/tidaknya pengaruh pemberian gel ekstrak air daun pepaya pada vagina mencit bunting dengan konsentrasi berbeda (5\%, $10 \%$ dan $15 \%$ ) dibandingkan kontrol. Sehingga ada kemungkinan terapi selama minggu-minggu terakhir kehamilan, sehingga proses degradasi kolagen yang sedang dan akan berlangsung saat kehamilan dan persalinan nanti dapat diseimbangkan dengan sintesa kolagen melalui pemberian topikal gel ekstrak air daun pepaya.

Studi pendahuluan kami lakukan karena tidak mendapatkan literatur yang menyatakan ada tidaknya perbedaan kepadatan kolagen antara organisme yang non bunting/hamil dan bunting/hamil (pada organisme bunting/hamil kepadatan kolagen berkurang). Satu literatur yang menyatakan bahwa pada hewan percobaan setelah bunting dan melahirkan, hasil pemeriksaan kepadatan kolagen pada serabut ototnya mengalami penurunan dibandingkan yang tidak bunting. ${ }^{18}$ Namun memang tidak dinyatakan secara eksplisit di jaringan vagina. Literatur lain menyebutkan kondisi kolagen pada saat prolaps bukan saat hamil atau setelah persalinan yang menyatakan penurunan signifikan kolagen fasia vagina pada wanita premenopause prolaps dibandingkan kontrol, serta peningkatan degradasi kolagen melalui pengamatan peningkatan aktivitas matriks metallo proteinase. ${ }^{8}$

Pada studi pendahuluan kami mendapatkan adanya perbedaan rerata kepadatan kolagen pada jaringan vagina mencit non bunting dengan mencit bunting dengan nilai $\mathrm{p}=0,16$ bila dinilai berdasarkan skor dan $\mathrm{p}=0,59$ bila dinilai berdasarkan persentase.

Namun hal ini tidak merepresentasikan bahwa tidak ada perbedaan kondisi kolagen saat bunting. Karena faktor resiko persalinan yang membawa dampak prolap organ panggul terjadi 1 di antara 3 wanita yang menjalani persalinan lebih dari 2 kali. Sebuah literatur menyatakan selain usia dan menopause yang berkolaborasi dengan jumlah persalinan selama wanita itu hidup adalah adanya peningkatan prolaps organ panggul 3,6 \% pada nullipara; $6,5 \%$ pada primipara; $22,7 \%$ setelah persalinan ke-2; $32,9 \%$ pada tripara dan 46,8 pada tetrapara. $^{19}$

\section{Karakteristik sampel penelitian}

Pada penelitian ini untuk mendapatkan sampel mencit yang homogen dilakukan pemilihan mencit yang seragam baik usia maupun berat badan kemudian dilakukan proses sinkronisasi birahi dan perkawinan mono mating, hari pertama kebuntingan didiagnosa pada saat ditemukan copulatory plug pada vagina mencit betina yang dikawinkan.
Setelah proses kebuntingan dan perlakuan, dilanjutkan pengambilan dan pemeriksaan sampel didapatkan sebanyak dua puluh empat sampel/preparat yang kemudian dilakukan pengecatan dengan HE (hematoxylin eosin). Dari 24 mencit, terbagi masing-masing kelompok sebanyak 6 mencit, kami sajikan karakteristiknya ditinjau dari berat badan induk saat bunting, berat badan dan panjang badan fetus, jumlah fetus yang dilahirkan per induk, ada/tidaknya cacat eksternal dan hari kebuntingan saat mencit melahirkan.

Semua karakteristik menunjukkan data yang homogen, artinya beban yang diterima oleh jalan lahir salah satunya vagina pada mencit masing-masing kelompok adalah sama. Berat badan dan panjang badan anak mencit masih dalam taraf normal. Normalnya berat badan anak mencit antara 0,5 - 1,5 gram dan panjang badan anak mencit $2,5-3,5 \mathrm{~cm} .{ }^{14}$ Tidak didapatkan cacat eksternal dari semua kelompok (berat lahir rendah, anggota tubuh tidak lengkap, mati).

Berat badan induk saat bunting hari ke-15 ditimbang karena kekhawatiran tidak sempat ditimbang bila lahir terlebih dahulu karena efek perlakuan, ternyata lahirnya anak mencit sebelum usia bunting 17 hari tidak terjadi. Analisa data berat badan induk saat bunting juga menujukkan data yang homogen.

Sebuah literatur menyatakan bahwa selain instrumentasi dalam persalinan (forsep dan vakum) dan lama persalinan, ukuran bayi yang besar yang dilahirkan juga turut menyumbang faktor resiko terjadinya prolaps organ panggul. ${ }^{20}$ Sebuah disertasi menyatakan berat bayi lebih dari $3325 \mathrm{~g}$ sudah mulai memberikan dampak pada organ panggul. ${ }^{21}$ Faktor lainnya adalah jumlah paritas (>3), semakin bertambahnya usia ibu dan BMI > $24 \mathrm{~kg} / \mathrm{m} 2$ jugamenambah resiko terjadinya prolaps organ panggul. ${ }^{19}$

Tidak didapatkan proses kelahiran anak mencit yang kurang dari 17 hari atau lebih dari 19 hari usia kebuntingan. Sedangkan jumlah anak fetus yang dilahirkan berkisar antara 3-15 fetus per induk. Namun yang diambil sebagai sampel untuk uji statistik adalah vagina induk mencit yang melahirkan anak mencit berjumlah 6-10, karena rata-rata mencit melahirkan 6-10, beberapa literatur menyebutkan 5-10. ${ }^{15}$

Sedangkan lama aplikasi gel pada penelitian ini berkisar 6-8 hari. Pada studi lain dilakukan aplikasi ekstrak daun pepaya pada gusi mencit terinfeksi \pm 6 hari dan aplikasi pada luka insisi tikus $\pm 23-28$ hari. ${ }^{11,13}$ Kedua penelitian tersebut sudah mendapatkan hasil yang bermakna pada konsentrasi tertentu terhadap pembentukan kolagen. 


\section{Perbandingan kepadatan kolagen jaringan vagina mencit pasca melahirkan antar kelompok}

Pada penelitian ini, data kepadatan kolagen berdasarkan penilaian skor diuji statistik Kruskal Wallis. Kepadatan kolagen baik berdasarkan skor maupun persentase antar kelompok (1-4) ada perbedaannya, dari skor didapatkan perbedaan signifiikan, dengan nilai $\mathrm{p}=0,036(\mathrm{p}<0,05)$, namun setelah dilakukan uji beda masing-masing kelompok dengan uji statistik Mann Whitney, ternyata kelompok 1 tidak didapatkan perbedaan ber-makna dengan kelompok 2, 3 dan 4. Memang dari uji statistik non parametrik Kruskal-Wallis (skor kolagen) ada perbedaan signifikan, namun perbedaan itu pada uji Mann-Whitney adalah antara kelompok 2 dan 3 (sesama kelompok perlakuan), bukan antara kontrol dengan perlakuan.

Adanya perbedaan uji beda ini disebabkan rentang persentase pada skor kepadatan kolagen nilai 2 dan $3( \pm$ $40 \%)$ yang lebar dibandingkan skor 1 dan $4( \pm 10 \%)$. Sehingga perbandingan persentase kepadatan kolagen berskala parametrik lebih sensitif/presisi menunjukkan perbedaan antara kelompok.

\section{Kepadatan kolagen jaringan vagina pasca melahirkan antara mencit kelompok perlakuan gel ekstrak air daun pepaya 5\% (2) meningkat dan berbeda signifikan dibandingkan dengan kelompok kontrol (I)}

Kepadatan kolagen berdasarkan persentase (parametrik), dari uji Anova didapatkan perbedaan masingmasing kelompok dengan nilai $\mathrm{p}=0,032$ dan uji beda antara kelompok dengan uji statistik LSD didapatkan perbedaan bermakna antara kelompok kontrol (kelompok 1) kelompok perlakuan gel ekstrak air daun pepaya konsentrasi $5 \%$ (kelompok 2), nilai $\mathrm{p}=0,045$ $(\mathrm{p}<0,05)$.

Pada perempuan yang tidak hamil, berkas kolagen pada serviks terbungkus rapat dan tidak beraturan. Selama kehamilan, kolagen secara aktif disintesis dan secara terus menerus diremodel oleh kolagenase. Kolagen didegradasi oleh kolagen intrasel yang menyingkirkan struktur prokolagen yang tidak sempurna untuk mencegah pembentukan kolagen yang lemah dan kolagenase ekstrasel secara lambat melemahkan matriks kolagen agar persalinan dapat berlangsung. ${ }^{22}$

Kolagen adalah komponen paling penting dari jaringan ikat yang berkaitan dengan kekuatan jaringan dan prolaps lebih sering terjadi pada wanita dengan gangguan metabolisme kolagen. Perubahan kolagen dan ketebalan serat telah diteliti secara histologis pada wanita dengan prolaps. Inkontinensia urin tipe stres meningkat pada wanita nulipara saat premenopause dengan kadar kolagen berkurang pada dinding anterior vagina mereka. ${ }^{8}$

Jackson et al menunjukkan penurunan signifikan kolagen fasia vagina pada wanita premenopause prolaps dibandingkan kontrol, serta peningkatan degradasi kolagen melalui pengamatan peningkatan aktivitas matriks metallo proteinase (MMP) dalam jaringan ini. Penelitian terbaru menunjukkan bahwa ada perubahan metabolisme kolagen yang terjadi pada ligamen uterosakral wanita dengan prolaps uteri. ${ }^{8}$ Sehingga keseimbangan sintesa dan degradasi kolagen penting dalam menjaga integritas jaringan dan kekuatan regangan selama remodelling jaringan berlangsung. ${ }^{10}$

Kolagen tipe I merupakan kolagen terbanyak pada jaringan ikat dan penting untuk fungsi dari matriks ekstraselular dengan kolagen tipe III, V dan VI dalam jumlah yang lebih sedikit. Kolagen tipe I berperan pada kekuatan regang (tensile strength) jaringan ikat, sementara kolagen tipe III berperan terhadap fleksibilitas/elastisitas. Mutasi dari gen kolagen tipe I dan III akan menyebabkan abnormalitas jaringan ikat dari kulit dan tendon, seperti sindrom Ehlers-Danlos, sindrom Marfan dan osteogenesis imperfekta. ${ }^{22,23}$

Kolagen tipe I merupakan $90 \%$ total kolagen pada mamalia. Kolagen ini disintesa oleh fibroblas, odontoblas dan osteoblas. Terdiri atas dua (2) rantai alpha-1 $(\alpha-1)$ dan satu (1) rantai alpha-2 $(\alpha-2)$, serta disusun menjadi serabut yang tebal sehingga memberikan ketegangan (tensile strength) pada struktur. Ditemukan pada, kulit, tendon, fasia, ligamen dan tulang. ${ }^{25}$

Kolagen tipe III tersebar bersama tipe I, tetapi rasio dari kedua tipe ini bervariasi pada jaringan yang berbeda. Terdiri dari tiga (3) rantai $\alpha 1$, bentuknya lebih pendek dan serabutnya lebih tipis. Disintesa oleh fibroblas dan sel retikuler. Perannya elastisitas, tersebar di kulit, otot, fasia dan ligament. ${ }^{25}$

Ekstrak daun pepaya mengandung zat kimiawi antara lain, papain, alkaloid, flavonoid, tanin, saponin, steroid, glikosid serta vitamin C. ${ }^{11,12}$ Kandungan saponin dan vitamin C ini yang berperan dalam sintesa kolagen. Saponin merupakan komposisi zat yang banyak ditemukan di beberapa tumbuhan. Penelitian menunjukkan bahwa saponin memiliki banyak aktivitas biologi antara lain, anti bakterial,anti virus, anti inflamsai berupa mengurangi edema dan berperan dalam proses penyembuhan luka. ${ }^{26}$

Peran saponin berupa modulasi sel fibrosit untuk mensintesa kolagen, sedangkan vitamin $\mathrm{C}$ berperan 
pada proses sintesa kolagen sebagai kofaktor enzim prolil hidroksilase pada pembentukan hidroksiprolin sebagai bagian dari sintesa kolagen. ${ }^{14,27}$ Pada penelitian ini digunakan daun pepaya berwarna hijau, dimana kadar vitamin C-nya lebih tinggi $(16,29 \mathrm{mg} / 100 \mathrm{~g})$ dibandingkan daun berwarna coklat ataupun kuning. ${ }^{28}$ Ekstrak saponin dikatakan menekan ekspresi MMP-3 dan mengurangi respon mediator pro inflamasi. MMP-3 bekerja mengkatabolisir kolagen tipe 3 , sedangkan mediator inflamasi TNF- $\alpha$ dan IL-1 $\beta$ merupakan stimulator berproduksinya MMP-3. ${ }^{26}$ Selain itu saponin meningkatkan proliferasi sel epidermal dan migrasi sel keratin pada proses penyembuhan luka, efek sintesa kolagennya melalui stimulasi fibroblas yang kemudian mensintesa kolagen dengan cara fosforilasi protein Smad 2 dan hambatan terhadap enzim MMP. ${ }^{26}$

Serabut kolagen yang dibentuk oleh fibroblast berasal dari ikatan hidroksiprolin dan hidroksilisin. Kedua ikatan tersebut terbentuk dari proses hidroksilasi, dimana yang berperan pada proses tersebut adalah enzym prolin dan lysil hidroksilase, dan sebagai kofaktor enzim tersebut adalah vitamin C. Disamping itu, secara in vitro vitamin $C$ juga berfungsi lain, yang tidak dimediasi secara enzimatis yaitu meregulasi dan menstabilkan transkripsi gen mRNA prokolagen pada proses pembentukan kolagen di dermis.

Hal ini berarti vitamin $\mathrm{C}$ dibutuhkan dalam proses sintesa kolagen. Apabila vitamin $\mathrm{C}$ dihilangkan dari diet manusia yang sehat maka manusia tersebut akan mengalami defisiensi vitamin $\mathrm{C}$ dalam 30 hari, meskipun sebelumnya kebutuhan vitamin $\mathrm{C}$ nya tercukupi. Penyakit yang disebabkan oleh kekurangan vitamin $\mathrm{C}$ disebut Scurvy yang ditandai dengan adanya gangguan sintesa kolagen. Vitamin $\mathrm{C}$ bersifat sangat larut dalam air (hidrofilik) dan dalam bentuk non ionic dapat menembus sel-sel dermis dengan cara berdifusi secara pasif. ${ }^{27,30}$

\section{Kepadatan kolagen jaringan vagina pasca melahirkan antara mencit kelompok perlakuan gel ekstrak air daun pepaya $10 \%$ (3) menurun dan tidak berbeda signifikan dibandingkan dengan kelompok kontrol (I)}

Pada konsentrasi $10 \%$ kepadatan kolagen justru menurun, hal ini kemungkinan pertama disebabkan efek saponin minimal terhadap sintesa kolagen dibandingkan efek papain yang semakin banyak (pada konsentrasi tinggi) bersifat degradator kolagen. Papain yang ada dalam daun pepaya merupakan proteinase sistein yang mengandung grup thiol sistein 27 yang memiliki aktivitas katalitik yang merusak ikatan peptida interfibrilar dari jaringan kolagen terutama pada ikatan antara peptida arginin, lisin dan glisin. Sehingga, papain dikatakan memiliki efek seperti kolagenase atau enzim MMP yang mengatur katabolisme kolagen. ${ }^{31,32}$ Pada penelitian untuk melihat aktivitas kolagenase papain, tampak degradasi kolagen yang ditunjukkan terbentuknya deposit nitrogen non protein , asam amino bebas dan hidroksiprolin pada pemberian papain $20 \mathrm{mg} / 100 \mathrm{~g}$ daging sapi selama 24-48 jam. ${ }^{31}$ Literatur lain menyatakan bahwa papain dapat melarutkan kolagen hingga $12,36 \%$, tertinggi dibandingkan protease jenis lain. ${ }^{33}$ Hal inilah kemungkinan menyebabkan degradasi kolagen lebih dominan saat konsentrasi ekstrak air daun pepaya ditingkatkan. Kedua, ternyata ada bukti yang menyatakan efek saponin malah menurunkan sintesa kolagen melalui penuruan aktivitas gen Col-1A2 dan Col-3Al yang bertanggung-jawab pada sintesa kolagen tipe 1 dan 3. Dengan pemberian saponin 10-20 $\mu \mathrm{g} / \mathrm{ml}$ dapat menurunkan ekspresi m-RNA TGF- $\beta 1$ dan $\mathrm{m}$ RNA Col-1. ${ }^{34}$ Ketiga, kemungkinan tidak adanya kandungan saponin atau bahkan vitamin $\mathrm{C}$ pada ekstrak yang telah dibuat karena tidak dilakukan pemeriksaan/ identifikasi zat aktif sebelumnya. Suatu penelitian zat aktif daun pepaya didapatkan pemeriksaan ekstrak saponin negatif pada penelitian di Bali. ${ }^{35}$

\section{Kepadatan kolagen jaringan vagina pasca melahirkan antara mencit kelompok perlakuan gel ekstrak air daun pepaya $10 \%$ (3) meningkat dan tidak berbeda signifikan dibandingkan dengan kelompok kontrol (I)}

Pada konsentrasi $15 \%$ kepadatan kolagen meningkat kembali walaupun perbedaan dibandingkan dengan kelompok kontrol tidak signifikan. Hal ini agak sulit dijelaskan, karena bila dipengaruhi papain, seharusnya kepadatan kolagen menurun. Kemudian kecurigaan apakah ada pengaruh perbedaan waktu dalam pengambilan sampel jaringan vagina pada kelompok ini. Proses penyembuhan luka terdiri atas 3 fase yaitu fase inflamasi, proliferasi dan remodelling. Fase inflamasi berjalan dalam kurun waktu 24-48 jam. Selanjutnya fase proliferasi berjalan mulai hari ke-3 sampai dengan minggu ke-2, dimana sel fibroblas mulai memproduksi kolagen. Dilanjutkan fase remodelling yang berjalan mulai minggu ke-2 atau ke-3 sampai maksimal 2 tahun. Sehingga hal tersebut kecil kemungkinannya terkait perbedaan waktu pengambilan sampel karena segera diambil kurang dari 24 jam. $^{36}$

\section{SIMPULAN}

Pemberian topikal gel ekstrak air daun pepaya konsentrasi $5 \%$ saat masa kebuntingan mencit meningkatkan kepadatan kolagen jaringan vagina pasca melahirkan. 


\section{DAFTAR PUSTAKA}

1. Suririnah. Buku pintar kehamilan dan persalinan. Jakarta: PT. Gramedia Pustaka Utama; 2008.

2. Department of Health. Statistical Bulletin-NHS Maternity Statistics 2001-2002. England, London. 2003.

3. Wagner M. Pursuing the birth machine: the search for appropriate technology. Camperdown: ACE Graphics; 1994. p. 165-74.

4. Graves EJ, Kozak LJ. National hospital discharge survey: annual summary. Vital Health Statistic. 1996;140:1-46.

5. Sultan AH, Kamm MA, Bartram CI, Hudson CN. Perineal damage at delivery. Contemp Rev Obstet Gynaecol. 1994;6:18-24.

6. Renfrew MJ, Hannah W, Albers L, Floyd E. Practices that minimize trauma to the genital tract in childbirth: a systematic review of the literature. Birth. 1998.

7. Alperin M, Feola A, Meyn L, Duerr R, Abramowitch S and Monali P. Collagen scaffold: a treatment for simulated maternal birth injury in the rat model. Am J Obstet Gynecol. 2010;202(6):589.

8. Phillips C, Monga A. Childbirth and the pelvic floor: The Gynaecological Consequensces. Reviews in Gynaecological Practice. 2005;5:15-22.

9. Tsai HC, Hong MC and Wu MP. The Alteration of Collagen Subtypes and Myofibroblasts may Account for Pelvic Organ Prolapse. Incont Pelvic Floor Dysfunct. 2011;5(2):47-8.

10. Kerkhof $\mathrm{MH}$, Hendriks L and Brölmann HAM. Changes in connective tissue in patients with pelvic organ prolapse - a review of the current literature. Int Urogynecol $\mathrm{J}$ Pelvic Floor Dysfunct. 2009;20(4):461-74.

11. Nugroho BD. Uji efektivitas ekstrak daun pepaya (Carica papaya) terhadap kepadatan serabut kolagen pada gingiva tikus wistar jantan dengan periodontitis eksperimental. Skripsi, Fakultas Kedokteran Gigi Universitas Jember. 2013.

12. Fachraniah, Kurniasih E, Azhar M. Pestisida alami dari daun dan batang pepaya. Skripsi. Fakultas Teknik Kimia Politeknik Negeri Lhokseumawe. 2013.

13. Kanzaki T, Morisaki N, Shiina R and Saito Y. Role of transforming growth factor- $\beta$ pathway in the mechanism of wound healing by saponin from Ginseng Radix rubra. Br J Pharmacol. 1998;125 (2):255-62.

14. Moore DM. Rats and Mice: Biology. Laboratory Animal Medicine and Science. Serise II. Washington, USA. Health Sciences Center for Educational Resources. 2000:1-23.

15. Pranandaru H. Pengaruh gel kombinasi ekstrak daun yodium (Jatropha multifada) dan daun pepaya
(Carica papaya) terhadap penyembuhan luka eksisi pada kulit tikus putih (Rattus novergicus) melalui pengamatan kepadatan kolagen. Skripsi, Fakultas Kedokteran dan Ilmu Kesehatan Universitas Muhammadiyah Yogyakarta. 2013.

16. Goldberg RP. Effects of pregnancy and childbirth on the pelvic floor. In Urogynecology in primary care. London: Springer; 2007. p. 21-33.

17. Hay-Smith J, Mørkved S, Fairbrother KA and Herbison GP. Pelvic floor muscle training for prevention and treatment of urinary and faecal incontinence in antenatal and postnatal women. Cochrane Database Syst Rev. 2008;8(4).

18. Baessler K, Schüssler B, Burgio KL, Moore KH, Norton PA and Stanton SLE. Pelvic Floor Reeducation. London: Springer; 2008.

19. Awwad J, Sayegh R, Yeretzian J and Deeb ME. Prevalence, risk factors, and predictors of pelvic organ prolapse: a community-based study. Menopause. 2012;19(11):1235-41.

20. Drutz HP, Herschorn S, Diamant NE. Anatomy of the Pelvic Floor. Female Pelvic Medicine and Reconstructive Pelvic Surgery. London: Springer; 2003. p. 25-35.

21. Santoso BI. Penentuan Pengukuran Sistem Indeks Untuk Memprediksi Kerusakan Otot Levator Ani Pada Persalinan Per Vaginam. Disertasi Doktoral, Fakultas Kedokteran Universitas Indonesia. Jakarta. 2012.

22. Sulin D. Perubahan anatomi dan fisiologi pada perempuan hamil. Ilmu Kebidanan Sarwono Prawirohardjo. Edisi ke-4. Jakarta: Bina Pustaka Sarwono Prawirohardjo; 2009.

23. Vulic M, Strinic T, Tomic S, Capkun V, Jakus IA and Ivica S. Difference in expression of collagen type I and matrix metalloproteinase-1 in uterosacral ligaments of women with and without pelvic organ prolapse. Eur J Obstet Gynecol Reprod Biol. 2011;155(2):225-8.

24. Augsburger HR, Oswald M. Immunohistochemical analysis of collagen types I, III, IV and alfa-actin in the urethra of sexually intact and ovariectomized beagles. Int Urogynecol J. 2007;18:1071-5.

25. Calvi EN, Nahas FX, Barbosa MV, Calil JA, Ihara SS, Silva Mde S, Franco MF, Ferreira LM. An experimental model for the study of collagen fibers in skeletal muscle. Acta Cir Bras. 2012;27(10):6816.

26. Kim YS, Cho IH, Jeong MJ, Jeong SJ, Nah SY, Cho YS, Kim SH, Go A, Kim SE, Kang SS, Moon CJ, Kim JC, Kim SH, Bae CS.Therapeutic effect of total ginseng saponin on skin wound healing. J Ginseng Res. 2011;35(3):360-7.

27. Murray RK, Daryl KG, Rodwell VW. Matriks Ekstrasel. Biokimia Harper. Edisi ke-27. Jakarta: EGC; 2006. 
28. Ayoola PB and Adeyeye A. Phytochemical and nutrient evaluation of Carica papaya (pawpaw) leaves. IJRRAS. 2010;5(3):325-8.

29. Kim KR, Chung TY, Shin H, Son SH, Park KK, Choi JH and Chung WY. Red ginseng saponin extract attenuates murine collagen-induced arthritis by reducing pro-inflammatory responses and matrix metalloproteinase-3 expression. Biological and Pharmaceutical Bulletin. 2010;33(4):604-10.

30. Darma S, Manjas M, Saputra D and Agus S. Efek Pemberian Suntikan Subkutan Vitamin C Terhadap Luka Insisi Dermal. Jurnal Kesehatan Andalas. 2013;2(3):168-9.

31. Ionescu A, Aprodu I and Pascaru G. Effect of papain and bromelin on muscle and collagen proteins in beef meat. The Annals of the University Dunarea de Jos of Galati. Fascicle VI-Food Technology. New Series. 2008;9-16.

32. Bertassoni LE, Marshall GW. Papain-gel degrades intact nonmineralized type 1 collagen fibrils. NIH public access. 2010;31(6):253-8.
33. Calkins $\mathrm{CR}$ and Sullivan G. Adding enzymes to improve beef tenderness. Beef Facts Product Enhancement, National Cattleman's Beef Association. Centennial Colorado: Cattlemen's Beef Board. 2007.

34. Gu J, Liu K, Li H, Wang X and Yang K. Astragalus saponin attenuates the expression of fibrosis-related molecules in irradiated cardiac fibroblasts. Acta biochimica et biophysica Sinica. 2014;46(6):492501.

35. Mahatriny NN, Payani NPS, Oka IBM, Astuti KW. Skrining Fitokimia Ekstrak Etanol Daun Pepaya (Carica papaya L.) yang diperoleh dari Daerah Ubud, Kabupaten Gianyar, Bali. Skrispi. Fakultas MIPA Universitas Udayana. Bali. 2013.

36. Hsu A, Mustoe TA. Fundamental principles of plastic surgery: The Principles Of Wound Healing. 2nd Eds. Plastics Surgery Secrets Plus. Philadelphia: Mosby Elsevier; 2010. p. 3-7. 